\title{
Five Pillars of Islam in Relation to Physical Health, Spiritual Health and Nursing Implications
}

\author{
Cho Cho Zaw @ Raheema ${ }^{1}$ and Myat Min @ Mohd Omar ${ }^{2}$ \\ ${ }^{1}$ Kulliyyah of Nursing, International Islamic University Malaysia ${ }^{2}$ Ph.D Candidate, Kulliyyah of Allied Health \\ Science, International Islamic University Malaysia
}

\section{ABSTRACT}

This study aimed to examine five pillars of Islam and their relationship with physical and spiritual health. The five pillars of Islam are the foundation of Muslim life, considered mandatory by believers, and Muslims are required to observe them with utmost dedication. They are summarized as Shahadah, Salah, Zakat Saum, and Hajj. he first pillar of Islam, declaration of faith (Shahadah) includes the most important concept, which is the complete submission to the will of Allah (SWT) by obeying and believing in Him. Spirituality in general is defined as "religious belief or the spiritual quality of something", "a search for the sacred", "personal growth, or an encounter with one's own inner dimension". The World Health Organization (WHO) mentions spiritual health as one of four dimensions to well-being; physical, mental, social, and spiritual". Moreover, holistic nursing practice includes treating people as a whole and attending to a client's physiological, psychological, and spiritual needs. Thus, this study intends to further explore the unitary aspect of Islam that infuse each of the pillars, and their effects on physical, spiritual well-being and nursing implications associated with it. Five pillars of Islam are discussed from the Quran, Alhadith, and Sunnah (the sayings and traditions of the Prophet) as baselines, and further additions from the knowledge of the Islamic scholars. And it is noted that our practices based on the five pillars of Islam have not only positive effects on physical but also spiritual health. This paper pointed out that while performing obligatory duties as stipulated by Islam, one could achieve spiritual enhancement as well as physical strength and well being.

KEY WORDS: five pillars of Islam, health, Spiritual health, Quran, Sunnah, Alhadith

\section{INTRODUCTION}

The term "spirituality" has a broader concept and meaning, and is often defined in relation to religion. It is regarded as "the quality or state of being concerned with religion or religious matters: the quality or state of being spiritual"1, "religious beliefs or the spiritual quality of something", "soul or inner life". More specifically, spirituality is interpreted as a sense of belonging, meaning and purpose in life, of connectedness, and of the openness to the infinite (Kelly, 1995) ${ }^{3}$. Religion is described as an organized set of practices that characterize a specific value, beliefs or faith.

In Islam, spirituality or rabbaniyat is "the elevation of the human condition to a plane on which the mind is focused on the higher, non-material realities of a Godly existence". ${ }^{4}$ Nonetheless, the discussion on spiritual aspect of a person will not be complete without mentioning the physical actions or behaviors. Physical body works under the control of the brain which itself works in service of the mind. The term "soul" is commonly used as "one's personality" or character, and is almost indistinguishable with ego, self, spirit or mind.

Cho Cho Zaw @ Raheema

Kulliyyah of Nursing,

International Islamic University Malaysia, Kuantan Campus.

Email : raheema@iium.edu.my
Believers are responsible for the purification of their soul or mind. They must always remain cautious about it, and purifies it, to achieve real success of this life and hereafter, as it is evident from the following verse of the Qur'an.

"By the soul, and the proportion and order given to it; And its inspiration as to its wrong and its right; Truly he succeeds that purifies it, And he fails that corrupts it." (Ash-Shams: 91: 7-10)

Fasting in the month of Ramadan is another spiritual training which is compulsory for all mature, healthy male and female Muslims. Ramadan, the ninth month of the Islamic lunar calendar is a special month blessed with spiritual atmosphere. During this month, Muslims are given the opportunity to fast from dawn to dusk and to make tarawih salah (extra prayers) at night. Fasting is known to have numerous benefits to both the physical body and the soul

Fasting involves worship as well as meditation and spiritual self-discipline ${ }^{19}$, the cause for learning Taqwa (Al-Baqarah 2:183). It nourishes our spiritual life, makes us humble and brings us closer to Allah. Thus, people who fast will attain inner peace and tranquility. Through fasting, the arteries which are blocked by the diseases of mercilessness are opened and cleaned, and hearts are inclined to the weak, needy and lonely people. ${ }^{20}$ In this way, fasting teaches us to value the blessings of Allah (SWT), to 
bring our heart closer to those who are in need and it furnishes our hearts with understanding, and empathy for them.

In addition to these, it has long been known that there are scientifically proven health benefits of fasting. These benefits include the elimination of harmful fatty substances from the blood, helping to cure certain types of stomach ailments and the renewal of body tissues as well as weight management. All these are achieved when the stomach, which is the root causes of diseases, takes a rest during the day when nothing is consumed. This enables stomach to do annual cleaning and repairing of the body system. ${ }^{8}$ Furthermore, if a man is trained through fasting to control his body and resist desires, certainly he can achieve in controlling other inappropriate desires, such as using drugs, alcohol, and involving in unlawful sexual relationship which all can affect their health and well-being.

\section{Saum or Fasting and Implications to Nursing}

Fasting is one of the methods of preventing certain diseases and the beneficial effects of observing fast regularly (few days per month) throughout the year as the traditions (Sunnah) of our beloved Prophet Muhammad (PBUH). Nonetheless, nurses may encounter some clients in the clinical area who do not want to miss their fasting especially during the month of Ramadan though it is not prescribed to them as compulsory. In this occasion, nursing care may need to be provided based on the clients' spiritual and cultural needs. The clients should be well-informed about the indications and contraindications of fasting with the medications, diet and treatment that they are receiving. If there are the potential risks associated with fasting, they should be advised to withhold it for later replacement when their condition is improved or stable.

\section{Preservation of Spiritual Health through Hajj}

Hajj (pilgrimage to Mecca) is prescribed to all Muslims who are physically, mentally and financially affordable to be carried out at least once in a lifetime. According to Al-Ghazali, pilgrimage in Islam occupies the place of monoasticism (rahbaniyyah) in the sense that all pilgrims, who have the intention to perform the pilgrimage, have to leave all worldly activities aside and proceed to concentrate fully on his pilgrimage, that is pray for forgiveness, devote one's self to dhikr. ${ }^{15}$ Since performing Hajj is a time for a man to dedicate himself entirely to his creator, by trying to obtain closeness to Him, it would be very helpful in preserving spiritual health and purity of a person. One needs to understand the real value of performing hajj so that the spiritual aspect of a person is achieved in the best and gracious manner.

Moreover, the hajj rites are fixed and have been handed down through the ages, and all Muslim pilgrims must fulfill each of the required acts. ${ }^{21}$ The main rituals of the hajj include "ihram, the state of ritual consecration in and around Mecca (ihram); circumambulation of the Ka'bah (tawaf); the ceremony of running seven times between Safa and Marwa (sa'i); standing (wuquf) at Arafah; stopping at night on the plain of Muzdalifah on the way back from Arafah; and stoning three symbolic stone pillars in the valley of Mina". ${ }^{16}$ These rituals of hajj helps the pilgrims to take examples of the sacrifices of Prophet Ibrahim, his wife Haja and son, Prophet Ismail (peace be upon them all). It leads them to reflect the patience, and endurance of Haja, running up and down between the two mountains to get water for her son, and the miracles water (Zam Zam) given to her by Allah (SWT).

Hajj redirects a person solely to a spiritual life because during hajj period, the manifestations of compassion, mercy, and love are seen clearly by not allowing for hunting, even killing a fly or pulling off a green leave. ${ }^{22}$ In hajj, the pilgrims need to wear the clothes with same color (ihram) regardless of their race, skin color, rank, and socioeconomic status. These create them to develop a sense of brotherhood, reduce social inequality, discrimination, and racism, that are the needed quality for the spiritual purification of human beings in the world.

Moreover, millions of people with different color, country, looks, and appearances are gathered together at the same time and place and special prayers are to be recited during the different rituals as mentioned by the Prophet Muhammad (PBUH). Thus, it is logical to say that when people are in the crowd of a million of people who are inspired by undergoing the same spiritual experience, they will naturally achieve spiritual strength and unity.

\section{Hajj and Implications to Nursing}

During hajj, all pilgrims from different background (sex, age, skin color, socioeconomic status, nationality and race) gather together and are all equal in front of their creator. This concept of equality should be part of the nursing care practices and the differences should never be the cause of any form of discrimination in clients receiving nursing care. Moreover, wearing 'ihram' (white clothes) in 'hajj' may make believers remember death which is the unavoidable part of life process and everybody's ultimate destination before meeting their creator. One of the nursing responsibilities include assisting the terminally ill and dying clients to get the maximum quality of life in their final days, and have a peaceful death by reducing their sufferings to a minimum and meeting their spiritual needs by allowing them to listen recitation of the Qur'an, "dua" and "shahadah".

Moreover, hajj conveys the stronger sense of community, harmony, unity and brotherhood spirit which is necessary to adopt in every community. The health sociologists claimed that the society with 
stronger sense of community and social cohesion live longer and healthier than those with lesser sense of community and social cohesion. Moreover, the health care needs of the millions of pilgrimages from all over the world need to be addressed and well-planned. The role of nurses should not be excluded here and the dedicated nurses with their knowledge and expertise are involved as part of the hajj medical and emergency team in cooperation with other health care professionals.

\section{Considerations for the Sick, Illness and Other Conditions}

Even though, the five pillars are regarded as the fundamental obligatory duties, there are certain conditions that a person can be excused from it. Allah (SWT) does not wish His devotees to harm themselves unnecessarily. Women during their menstrual periods are excused from conducting salah. A disabled or a sick person can perform the prayer while sitting or lying down position or in whatever manner is comfortable, but when he recovers, after any length of time, he is expected to perform salah in the normal way. Anyone who fears falling ill or fears that his illness would become more acute, or prolonged can resort to tayammum (clean sand or earth) for taharah (purification) instead of using water. ${ }^{23}$ In regards to fasting, a person may break the fast if it can adversely affect his health. Children below the age of puberty, insane and retarded people, the elderly, the sick and the travelers are exempted from obligatory fasting of Ramadan.

The Holy Qur'an mentions that "Fasting for a fixed number of days, but if any of you is ill, or on a journey, the prescribed number should be made up from days later. For those who can do it with hardship is a ransom, the feeding of one that is indigent. But he that will give more of his own free will, it is better for him. And it is better for you that ye fast" (Al-Baqarah 2:184). ${ }^{5}$ According to the alhadith, Allah's messenger (sometimes) did not fast during the journey (Sahih Bukhari), and thus fasting is not compulsory for a traveler. Whoever is able to fast can fast and whoever not able to fast can do so as well.

Moreover, the fatwa committee of al-Azhar issued a fatwa that a person suffering from a heart problem, whom the physicians have recommended not to do fasting, is encouraged to follow the doctors' advice and to fast only after recovery, or give two meals to one poor person for each day of the fast he misses. ${ }^{16}$ Similarly, women during menstruation, post-natal period, pregnant and lactating women are excused from fasting. But, they need to compensate for their missed days by feeding the poor and needy. From these observations, it can be concluded that Islam is a moderate religion, which follows the middle path between extremism and negligence, and which never neglects the important aspects of health and well-being.

CONCLUSION
From all the reasons mentioned above, five pillars of Islam have been prescribed by Allah (SWT) and it is known to have numerous physical, mental, social, spiritual and other unaccountable benefits. By practicing and acting accordingly, it could enhance the character and manner of an individual which helps lead to the betterment of the society. It is also hoped to add value to our daily practices and belief system after realizing the importance of the obligatory duties of Islam. It is clear that some divine secrets and knowledge can only be comprehended and achieved by those who have healthy body and sound minds. Since the best gift from Allah (SWT) is good health, everyone should obtain that goal by preserving it for now and the future. ${ }^{24}$ Preserving health and maintaining longevity as possible is part of a Muslim's responsibilities, and helping or assisting others to achieve is part of nurses' responsibilities. We should strive to get more understanding of the connection between physical and spiritual health and religious practices so that we make use of this knowledge for this life and hereafter. It is important to treat our heart, correct it and purify it from sickness and all the sins by practicing the basic religious obligations of Islam. Thus, the practices based on the five pillars of Islam have not only positive effects on physical but also spiritual health. While performing obligatory duties as stipulated by Islam, one can achieve spiritual enhancement as well as physical strength and well-being.

\section{REFERENCES}

1. Merriam-Webster dictionary, www.merriamwebster.com

2. Macmillan English Dictionary for Advanced Learners: New Edition. London, United Kingdom: A\&C Black Publishers Ltd, 2007.

3. Kelly, E. W. Jr. Spirituality and religion in counseling and psychotherapy. Alexandria, VA: American Counseling Association, (1995).

4. Maulana Wahiduddin Khan, Spirituality in Islam. 1997. Pdf. Retrieved from http://cpsglobal.org/sites/default/files/Spirit ualityinlslam.pdf; also can be viewed on http://www.spiritofislam.co.in/spiritnew/inde x.php/ari4

5. The Presidency of Islamic Researches, IFTA, eds. The Holy Qur'an: English translation of the meanings and Commentary. The Kingdom of Saudi Arabia: King Fahd Holy Qur'an Printing Complex, $1410 \mathrm{H}$.

6. HarunYahya. The purpose of a believer's life, The approval of Allah: Devoted to Allah. $1^{\text {st }}$ ed. New Delhi, India: Goodword Books, 2003.

7. Muslim American Society. 40 Hadith Nawawi 3 (Bukhari and Muslim). Retrieved from http://40hadithnawawi.com/index.php/thehadiths/hadith-3

8. Deuraseh, Nurdeng. Preservation of Health in Islamic Law. Malaysia: IIUM Press. 2009.

9. Shaheed, Shaikh Hasan Al-Banna. The Concept of Allah in the Islamic Creed. Delhi: Adam Publishers \& Distributors, 2000. 
10. Al-Tantawi, Sheikh Ali. General Introduction

To Islam. Makkah, K.S.A: Al-Manara Publishing and Distributing House, 1994.

11. Abdalati, Hammudah. Islam In Focus. Dehli: Rahmah Publishers, 1999

12. Bill McLean, (conv). Hadith Sahih Muslim. Pdf Retrieved from

https: / /www.shareislam.com/order/books/Sa hihMuslim.pdf

13. Hirschfelder, Umm Abdurrahman Sakina. Who Is Allah?: His Names and Attributes and their Significance to the Individual. Sawdi Arabia: International Islamic Publishing House, 2010.

14. Al-Qaradawi, Yusuf. The lawful and the prohibited in Islam (Al-Halal wal Haram fil Islam). Kuala Lumpur: Islamic Book Trust, 2001.

15. Rahman, F. Health and Medicine in the Islamic Tradition: Change and Identity,

16. USA: Crossroad Publishing Company, 1989.

17. Athar, Shahid. Islamic perspectives in medicine - A Survey of Islamic Medicine: Achievements \& Contemporary Issues. Indianapolis, USA: American Trust Publications, 1993.

18. Saniyasnain Khan. Tell Me About The Prophet Muhammad; What The Prophet's Message Is, Why His Life Is So Important And What He Teaches Me. $2^{\text {nd }}$ Ed. New Delhi, India: Goodword Books Pvt. Ltd, 2003.

19. Barkan, S.E, Sociology: Understanding and Changing the Social World, Brief Edition, V. 1.2 http:/ /2012books.lardbucket.org/pdfs/sociolo gy-brief-edition-v1.0.pdf Retrieved on 15th September 2016

20. Bennett, Clinton. Rituals and Spirituality, Studying Islam, London: Continuum International Publishing Group, 2010.

21. Osman Nuri Topas. The Secret in the love for God. Istanbul, Turkey: Erkam Publications, 2009.

22. Porter, Venetia, eds. Hajj journey to the heart of Islam. London: The Trustees of the British Museum, 2012.

23. Kaya, Murat. The final Divine religion, Islam. Istabul, Turkey: Erkam Publications, 2009.

24. Ibn al-Qayyim, Zad al-Ma'ad (Provisions for the Hereafter). http://www.dawahmemo.com/ image/2012-09-21-

25. 11_41en_Complete_Zaad_al_Maad.pdf

26. Freely, John. Light from the East: How the Science of Medieval Islam Helped to shape the Western World. London: I.B. Tauris \& Co Ltd, 2011. 